molecules; and the amount of force exerted is different for different elementary molecules. Hence chemical affinity is a positive force. The mutual action and reaction between the molecular systems involves the loss (or gain) of energy, but this loss of energy does not furnish a complete account of the action.

Thermal measurements enable us to determine the quantity of energy entering or leaving a given chemical system during its passage from one state to another. These measurements, therefore, give us most valuable information concerning the phenomena exhibited by those chemical systems.

The results obtained by these measurements show how great is our ignorance with regard to the progress of chemical reactions in general; and they suggest many exceedingly interesting problems which will doubtless ere long meet with satisfactory solution. The great problem of chemistry is to determine the connection between the structure and the properties of molecules. To take a special case, it may be asked, why is the hydrogen of acids replaceable by metals under definite conditions? Many facts are known which enable us to give partial answers to this question; doubtless, thermal investigation, taken in conjunction with other methods of research, will some day furnish the complete answer.

Thermal measurements have already shown us that allotropic changes in elementary molecules are accompanied with changes in the energy of these molecules and that the same generalisation holds good with regard to isomeric changes among compound molecules. But the whole question of allotropy is yet in its infancy.

The thermal method promises to throw light upon those phenomena which are classed together under the name of valency, and perhaps to furnish an answer to the query, why does the ralency of elementary atoms vary? The new method is full of hopeful anticipations.

M. M. Pattison Muir

\section{ARE THERE NO EOCENE FLORAS IN THE} ARCTIC REGIONS ?

N NATURE (vol. xix. p. 124) I expressed doubt whether 1 the beds containing fossil plants in or near the Arctic circle, said by Heer to be miocene, are really of that age. It seemed to me then very probable, but now I may say certain, that at least all those said to be lower miocene are truly eocene. The article was translated in Das Ausland, No. 2, 1879, and replied to by Heer in No. 8 (February 24) of the same journal. In this reply he, as I expected, combats my views, and, although affecting to believe that I had written without thought or previous study, he devotes eight columns to contradicting me, yet without bringing forward any fresh evidence whatever, or indicating any sources of information which I had not already consulted.

Heer contends that all the known fossil floras containing dicotyledons, from all lands within at least 2,000 geographical miles of the Pole, are either cretaceous or miocene. I think, on the contrary, many of them are eocene.

The leading facts for and against the hypothesis of a miocene age for so large a proportion of them may be briefly summarised.

I. The great similarity of the fioras (miocene of Heer) of latitude $70^{\circ}$ to those of $47^{\circ}$ and $46^{\circ}, 98$ species out of 363 , or more than 25 per cerit. being common to both, even in the present state of our knowledge. This, according to existing plant-distribution, precludes their being of the same age, unless the more southern ones grew in Alpine or even billy regions; but no one has ever contended that they did do so. No floras so much alike, and assimilating so closely to those of the present day, could have grown simultaneously at the same level in such widely different latitudes.
Against this Heer states that a number of trees extend from the borders of Italy to the 7oth parallel, as the firs, birches, aspens, bird-cherry, and mountain-ash. This fact has little bearing on the subject, since the trees are Alpine, or, at least, not in any way characteristic of the lowland flora of North Italy or of that latitude in Europe. Secondly, he says that of the fifty-nine phanerogams found by Feilden in Grinnell Land between $81^{\circ} 44^{\prime}$ and $83^{\circ}$, forty-five are European, and six of these are not only found in Swiss valleys, but also in Italy. This should not have been advanced, being quite beside the question, unless he wishes to make believe that the present floras of Grinnell Land and Italy resemble each other. They are, in fact, all Alpine herbaceous plants, and have nothing to do with the fossil forest floras in question; besides which, the level of the Swiss valleys in which these six grow is not stated, and there is nothing curious in Alpines ranging into Italy. Thirdly, of 559 species of phanerogams of the Isle of Saghalien, 188 are found in Switzerland. Such occasional examples of wide lateral distribution among plants are well known, and might often be adduced, without affecting the question in the remotest degree. The present distribution of the same types ot plants, trees, \&c., as those which are found fossil, have alone any bearing on the subject. Heer, to sustain his theory, must prove that forest floras extend in some other parts of the world with a much less degree of change than we have experience of in ou rcontinent, over not less than $30^{\circ}$ of latitude, and in about the same longitude.

2. The extreme improbability that the plant remains of the eocene, a far more important formation than the miocene, should have been alone overlooked in a series of deposits abounding in plants of immense extent and thickness, and continuous, it is supposed, from the middle cretaceous to the upper miocene. The absence of any intelligent explanation of the complete break in the sequence, which Heer's nomenclature implies, and of which there is not the least stratigraphical evidence. The vastness and immense extent of the formations which are ascribed to miocene. The universally admitted fact that continuous land existed in the north between Europe and America from early eocene times, as proved by the palæontological records of both continents, and supported by other considerations, and which must have left records at least in proportion to those of the miocene, since volcanic, the preserving agency, was active throughout the whole time.

Heer characteristically meets these important objections by stating that at Eisfiord, in Spitzbergen, there are I,, 00 feet of strata between the cretaceous and miocene, which he thinks doubtless represent the eocene. It is strange to find any one with the least knowledge of stratigraphical geology simple enough to advance such evidence as the presence of $1, \infty$ feet $^{\circ}$ beds at a single spot, in dealing with so colossal an interval as that between the cretaceous and miocene, especiaily when the latter alone, over the area, is several thousands of feet in thickness. Besides Nordenskjöld, ${ }^{1}$ from whom Heer derives his information, says that the miocene (of Heer) habitually rests upon the cretaceous.

Heer further says that there is a deposit with lower miocene mollusca under a miocene deposit. This is exactly what I should expect; for the same reasons that make it improbable that the flora is miocene apply equally to these mollusca.

3. The much higher temperatures which prevailed in the eocene than in the miocene, and which could only have permitted the growth of such temperate floras in such high latitudes in the eocene period, according to existing laws of plant distribution.

Although I showed seriatim that a mean temperature higher by $20^{\circ} \mathrm{F}$. in the northern hemisphere would inevitably have produced approximately just the series of ${ }^{2}$ Excursion to Greenland, Geol. Mag, vol ix. 
eocene floras that are met with in England, Iceland, Greenland, Spitzbergen, and Grinnell Land, and that from Heer's miocene standpoint no uniform increase could do so, his eight columns of reply do not embrace this question.

4. The total absence of any characters among the plants themselves, which would preclude their being considered eocene.

To this I must also await an answer until eocene floras are better understood. Heer's reply contains none.

It is obvious that if he has no more to say than this, the balance of the evidence, even as it stands, is already actually against him. But it is far more conclusive than I have represented it to be in the above summary.

We are told to believe that enormous deposits, many thousand feet in thickness, vast in extent, and resting everywhere conformably on the latest cretaceous beds, and indeed stratigraphically indistinguishable from them, are not as we should expect, in greater part at least-the next succeeding older tertiaries, but the miocene. We are not to question the reality of the marvellous gap thus created; not to point out that climatic considerations are entirely against the miocene age of the beds; not even to suggest that the plant evidence relied upon quite fails to support it; for Heer, like an infallible Pontiff, has, on plant evidence, pronounced them miocene.

$\mathrm{He}$ has tried to excommunicate me in his concluding paragraph, of which the following is but a feeble translation :- "The incorrect assertions and conclusions of $\mathrm{Mr}$. Gardner proceed from want of knowledge or disregard of well-ascertained and solid facts, and it is much to be desired that those who occupy themselves with such difficult questions should first acquaint themselves with the facts before they express upon them such positive opinions."

I, however, to use a quatation, do not feel "one penny the worse."

The miocene hypothesis, which is not a scientific one, and would have been gladly overturned by Belt, rests entirely upon Heer's interpretation of the plants. I have therefore, I presume, but to show how completely unreliable in this case Heer's interpretation is, to break the spell of infallibility attaching to his work and to reopen the question for solution by scientific thought-." the application of past experience to new circumstances, by means of an observed order of events," as Clifford put it. In the first place, what are the "well-ascertained and solid facts" of Heer? I have looked at the Bovey Tracey beds formerly described, and erroneously, as miocene by Heer. Taking the ferns, with which I am just now most familiar, I find a form described as Pecopteris lignitum, and this species was at the time no doubt a "solid fact;" but I subsequently find Heer describes this same fern as Aspidium lignitum $^{1}$ and, extraordinary to relate, as Dryandra rigida. ${ }^{2}$ Are these solid facts? Because he how speaks of the species as an Osmunda. I might analyse Heer's "solid facts" to a considerable extent, but refrain from doing so until the proper time arrives, in the pages of the Palæontograpbical Society. In the meantime I cannot but consider that his caution might more justly be applied to himself; for whilst I, at least, have had access to all Heer's published facts, I expressly stated that those I chiefly relied upon were unpublished. ${ }^{3}$ I therefore marvel that he should have written so positively on so difficult a question without first, at least, endeavouring to acquaint himself with the latest facts.

Heer either does not possess, it appears, the knowledge requisite to separate stages of the eocene from the miocene, or he misapplies it. Of all the floras he has described but one is for him, eocene, and about this he ex-

\footnotetext{
1 "Sächsisch-thüringischen Braunkohlenflora," 186 r, pl. ix. f. 2.$$
\text { In cuurse of pullication hy the Palrecntographical Suciety. }
$$

presses the greatest doubt. This single "great work" I on the eocene, as he calls it, was no larger than could be amply illustrated in ten not over-crowded plates, for I find the same species doing duty on more than one under different names. Beyond this he only claims to have studied the flora of Monte-Bolca, although he has published nothing upon it, and to have seen "many plants of the English eocene." Of the Monte-Bolca flora I can say little, as when I have been to Verona, where, I believe, large collections exist, the curator has been absent; but of the latter I can say that Heer's "many" must be used in a limited sense, for when he risited England, before either Mitchell or myself had commenced collecting, the collections open to him were meagre indeed.

Although, however, Heer modestly claims to have described but one eocene flora, I believe credit is due to him for describing several. Among these the most familiar to us is that of Bovey Tracey, lithologically and palæontologically precisely resembling some of the middle eocene beds of Bournemouth, only eighty miles distant from it. ${ }^{2}$ Heer may, of course, deny their eocene age, and I cannot convince him by letting him see the specimens, as I did Ettingshausen, who, after being shown leaves, fruits, seeds, and spines, said the matter must be considered doubtful unless I could produce Sequoia Couttsia from Bournemouth. This, on looking through the cabinet of conifers, we found in abundance, not only from Bournemouth, but also from Alum Bay. This is but one instance selected from near home. If we look at Heer's tables in the third volume of his "Flora Tertiaria," we see that all the floras of France, Germany, Austria, Italy, and Switzerland are called miocene. The floras of Sotzka, Häring, Monte Promina, \&c., although eocene to those who described them, are not so to Heer. He, in fact, persistently misrepresents the relative importance of the eocene and miocene formations, which he has always reversed, almost ignoring, indeed, the existence of the far more important of the two. Fortunately, accident has given to me what it has denied to Heer after a life of study, that is, access to large series of undoubted middle eocene plants ; for my own collection, from Bournemouth alone, cannot number less than I0,000 selected specimens. These plants reveal how closely many of Heer's so-called lower miocene floras assimilate to the eocene, to which age they doubtless belong, and that forms thought to be characteristic of the former are really only met with in the latter, and that other species, ranging through both, are misleading and negative, so far as affording evidence upon this question. Of course Heer could not be acquainted with the unpublished English floras, and unfortunately their publication must be a work of time; but why, for example, in opposition to Unger and Ettingshausen, did he maintain the Sotzka, Häring, and Monte Promina floras to be miocene.

$$
\text { "When next you view, }
$$

Think others see as well as you."

is the moral of a fable with which Heer seems unacquainted.

1 know that in very many cases what is lower miocene to Heer, is lower or middle eocene to me, and that therefore his lower miocene floras are practically and truly my middle or at latest upper eocene floras. There is thus a great difference of opinion between us, for the one nomenclature often implies immense gaps, which the other fills up.

While Heer's opinions of the ages of his localised floras are mostly based upon the evidence of the plants themselves, and the beds in which they are found contain little or no internal evidence, apart from this, of the formations to which they belong-those upon which I am

\footnotetext{
".Der sächsicch-thüringischen Braunkohlenth ra," Berlin, 1861 .

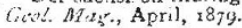


at work are upon stratigraphical evidence certainly of the ages to which they are ascribed.

We have a limited Thanet sand flora; a considerable insight into the Woolwich and Reading Beds flora, obtained from Dulwich, Reading, Newhaven; an Oldhaven flora from Bromley; an extensive London clay flora from Sheppey; a Lower Bagshot flora from Alum Bay, Studland, and Corfe; a Middle Bagshot flora from Bournemouth and Bovey Tracey; upper eocene floras from Hordwell, Gurnet Bay, \&c. All these will be embraced in the monograph now in course of publication by Ettingshausen and myself.

The nearly unbroken sequence seen in the eocene floras extends into the miocene. There is no great break in passing from one to the other when we compare them over many latitudes, and but little change, beyond that brought about by altered temperature or migration. If tertiary floras of different ages are met with in one area, great changes on the contrary are seen, and these are mainly due to progressive changes in climate. From middle eocene to miocene the heat imperceptibly diminished. Very gradually the tropical members of the flora disappeared; that is to say, they migrated, for most of their types, I think, actually survive at the present day, many but very slightly altered. Then the sub-tropical members decreased, and the temperate forms, never quite absent even in the middle eocenes, preponderated. As decreasing temperature drove the tropical forms south, the more northern must have pressed closely upon them. The northern eocene, or the temperate floras of that period, must have pushed, from their home in the far north, more and more south as climates chilled, and at last in the miocene time, occupied our latitudes. The relative preponderance of these elements, I believe, will assist in determining the age of tertiary deposits in Europe, more than any minute comparisons of species. Thus it is useless to seek in the Arctic regions for eocene floras, as we know them in our latitudes, for during the tertiary period, the climatic conditions of the earth did not permit their growth there. Arctic fossil floras of temperate and therefore to Heer miocene aspect, are in all probability of eocene age, and what has been recognised in them as a newer or miocene facies, is due to their having been first studied in Europe, in latitudes which only became fitted for them in miocene times.

When stratigraphical eviderce is silent or inconclusive, this unexpected persistence and migration of plant-types or species throughout the tertiaries, should be remembered, and the degrees of latitude in which they are found should be well considered before conclusions are publishea respecting their age.

I need not here point out how completely this theory accords with that of the dispersion or migration of species from a northerly centre, so ably treated of by Asa Gray, Dawson, Dyer, Saporta, Hooker, and in fact by all who have pondered upon the subject, excepting Heer, for I hope to write a few words upon this at a future time. Before quitting it, for the present, Heer may as well learn that I am not alone in my opinions, for Prof. J. W. Dawson, of Montreal, considers with me that the reference of the beds in Greenland to miocene is not warranted by comparison with the tertiary plants of America.

"Immediately above these upper cretaceous beds we have the great lignite tertiary of the west-the Laramie group of recent American reports-abounding in fossil plants, at one time regarded as miocene, but now known to be lower eocene, though extending upward toward the miocene age. These beds, with their characteristic plants, have been traced into the British territory north of the $49^{\text {th }}$ parallel, and it has been shown that their fossils are identical with those of the McKenzie River Valley, described by Heer as miocene, and probably also with those of Alaska, referred to the same age. Now this truly eocene flora of the temperate and northern parts of America has so many sfecies in common with that called miocene in Greenland, that its identity can scarcely be doubted. These facts have led to scepticism as to the miocene age of the upper plant-bearing beds of Greenlard, and more especially Mr. J. Starkie Gardner has ably argued, from comparison with the cocene flora of England and other considerations that they are really of that earlier date." 1

Private correspondence has already informed me that. others now share in these views.

Not content with withering my theories as to the eocene age of part of his miocene Arctic floras, Heer tilts against my explanation of the former higher temperatures which are known to have prevailed in our own and more northern latitudes. My explanation is, however, justified by our experience of what we conceive to be natural laws, and does not contradict that experience, and Heer has no theory to set up in its place.

The differences in the temperatures of the seas washing Arctic lands in the same latitudes are seen to alter: the isothermal temperatures of their coasts to the extent of $27^{\circ}$; that is to say, the coasts which are refrigerated by the descending ice-laden currents are $27^{\circ}$ colder than the shores of the North Cape, which are washed by an ascending current. With this fact and its causes palpably before us, we are justified in inferring that if the cold currents were shut off from these coasts, their temperature would rise by some $27^{\circ}$. The cold currents were shut off in the eocene time, for plants and animals passed freely between Europe and America, and therefore the temperature of the northern eocene lands may have been from this cause some $27^{\circ}$ bigher. But the Arctic eocene floras only required about $20^{\circ}$ higher temperature, and the cause involked is therefore more than sufficient.

Heer agrees with me that the higher temperature at the North Cape is due to warmer sea, and that continents. extending far south also have their infuence. He objects that Spitzbergen, keing within the influence of the Gulf Stream, has a temperature of only $7^{\circ}$ above the mean of its latitude. But then Spitzbergen is not shut in by the Gulf Stream, but only washed along one shore by it, and that after its current had been enfeebled and refrigerated to the last degree by the icy water it has to press through. Yet slight as the cause then is, it raises the isotherm of Spitzbergen $7^{\circ}$. He again objects that the closing of these outlets would stop the flow of the Gulf Stream. This, however, would not be the case completely, As long as any difference existed between the temperature to the north, and that under the tropics, a circulation would. continue and would only cease when the whole Atlantic. north of the Equator, had reached a uniform heat. Not streams only, but the whole Atlantic from the Equator northwards, would be enormously warmed, and even. parts of continents most remote from seas, would feel the influence.

This theory if true, Heer says, is at all events not original. In that case, so much the more likely to be true, but it is original to me. ${ }^{2}$. It is true that very many theories. have been put forward to account for former temperatures, and some of these have been based upon altered distributions of land and sea. But while some required change in the level of the sea, and others involved entirely novel continental areas, none have been supported by any kind of proof, either that the supposed changes had actually taken place, or were even competent to account for the former temperatures. The theory I have ventured to put: forward is only absurd in its simplicity. The Atlantic may be likened to a great bath heated by the sun, from which we may shut off the cold taps either partially or entirely, from one or from both ends, thereby producing.

I "The Genesis and Migrations of Plants," by J. W. Dawson. The Princeton Review, 1879, p. 282 
any known gradation of sea temperature. It not only accounts for the eocene heat when the land in the 7oth and 8oth parallels was upheaved by enormous volcanic action; the cooler miocene brought about when this action subsided, and permitted Arctic seas to again find egress; and the cold glacial period when both shores of the Atlantic were frozen by icy currents, as one shore is now ; but by shutting off Antarctic currents it might have produced the hottest cretaceous times. Even the latter supposition is rendered likely by the past and present distribution of life, and such conditions doubtless did exist in remote times.

I am, however, speculating beyond the scope of my present paper, for, however the eocene climate was produced, the Arctic floras, I believe, flourished in it. Again I will close my paragraph with an extract from Dawson: ${ }^{1}$ "But overlying this plant-bearing formation we have an oceanic limestone (the Niobrara) .... indicating that the land of the lower cretaceous was replaced by a vast Mediterranean Sea, filled with warm water from the equatorial currents, and not invaded by cold waters from the north. This is succeeded by thick upper cretaceous deposits. . . these show that further subsidence or denudation in the north had opened a way for the Arctic currents, killing out the warm-water animals of the Niobrara group, and filling up the Mediterranean of that period." J. STARKIE GARDNER

\section{AN ENGLISH MICROSCOPE FOR THE USE OF STUDENTS OF MINERALOGY AND PETROLOGY}

T $\mathrm{T}$ may interest those who are studying petrology to know that a new microscope, specially suited for mineralogical and petrological research, has recently been constructed by Mr. T. W. Watson, of Pall Mall.

For several years past students have frequently asked me to recommend some microscope to them which would answer their requirements, and, finding that none of the cheaper instruments manufactured in this country were supplied with concentrically-rotating stages, bearing divided circles, and that even the high-class instruments failed to fulfil all the requirements, it appeared that this want might be supplied at a moderate cost, if one of our instrument-makers could be induced to make a few trials.

An examination of one of the microscopes devised by Prof. Rosenbusch and manufactured by Fuess, of Berlin, showed me that, although that instrument possessed many features of great merit, it also had certain defects which could be best overcome by adopting and modifying a good English model.

The great defects in most of the microscopes built on the continental patterns consist in their fixed vertical position, the smallness of their stages, and, very commonly, in the absence of any means of coarse adjustment, except by a sliding movement of the body or tube, which, if working stiffly, is very inconvenient, while, if sliding easily, is apt to be shifted by a very slight touch.

The microscope of Prof. Rosenbusch, apart from one or two of these defects, is a very admirable instrument, and presents various advantages over all other microscopes hitherto made.

The instrument, now manufactured by Mr. Watson, is in most respects quite equal in performance to Rosenbusch's microscope, so far as the mechanical appliances and adjustments are concerned, and is, I think, in point of convenience, decidedly superior to the latter instrument.

The foot is a brass casting of a pattern somewhat similas to that of Ross and other well-known makers. Upon this a gun-metal limb is supported on trunnions, which constitute the axis upon which the limb turns, so that the instrument can be inclined at any angle, or placed in a horizontal position for drawing. The right trunnion 'The Princeton Revicw, $1879, \mathrm{p}, 282$ carries a clamp to fix the instrument at any angle. The lower portion of the limb bears the mirror, attached to a jointed arm. The upper part of the limb is bowed, or goose-necked, which renders it convenient as a handle, by which to lift the stand, without entailing any strain upon the working parts of the instrument. Above the curve it is ploughed out to receive the rack of the body or tube (on the pattern known as the "Jackson Model"), and the coarse adjustment is effected by a pinion turned by milled heads. The fine adjustment is of the usual kind, and is situated near the lower extremity of the tube. In the stand first made the milled head of the fine adjustment was divided for the measurement of the thickness of sections, but in future it is proposed to effect this object in a different manner by divisions engraved upon the limb and the sliding portion of the coarse adjustment.

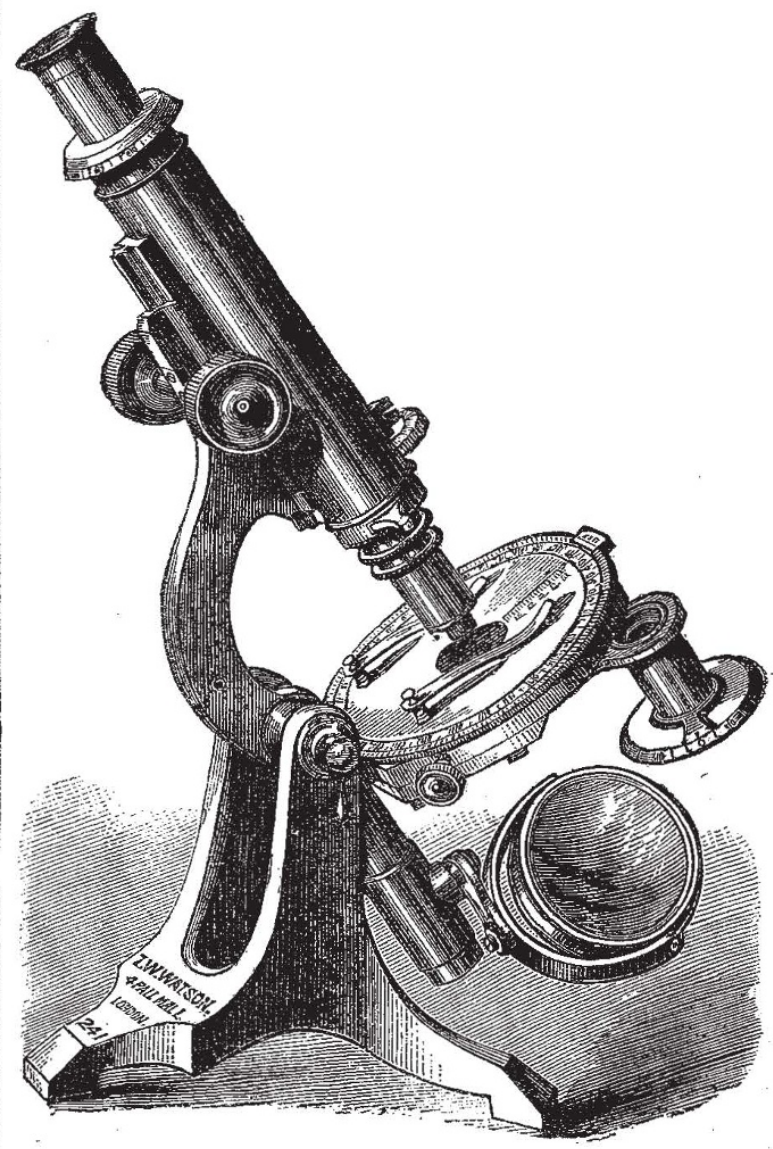

The head of the tube or body carries a bevelled disk which is divided to $10^{\circ}$ spaces. A corresponding disk with an index is attached to the bottom of the analyserfitting, and rests directly upon the fixed divided disk; so that the analyser can be set in any required position, and any amount of revolution imparted to it can also be registered. The eye-piece, when inserted, is kept in a fixed position by a stud, which falls into a small slot. Crossed cobwebs are fixed within the eye-piece for the purpose of centring the instrument. A small plate of calc-spar, cut at right angles to the optical axis, is mounted in a little metal ring, which can be placed between the eye-glass and the analyser for stauroscopic examinations.

At the lower end of the microscope-tube a slot is cut to receive a Klein's quartz plate or a quarter-undulation plate, both of which are set in small brass mounts. When these are not in use the aperture can be closed by means of a revolving collar. 